\title{
Anthropocentrism: The Importance of Traditional Oil Mining in Sustainable
} Development

\author{
Vieronica Varbi Sununianti ${ }^{1} *$ \\ ${ }^{1}$ Sociology Major, Faculty of Social and Political Science, Sriwijaya University \\ *Corresponding Author's e-mail address: vieronicavarbis@unsri.ac.id
}

Article history

\begin{tabular}{llll}
\hline Received & Received from reviced & Accepted & Available online \\
8 November 2018 & 27 December 2018 & 4 January 2019 & 11 Januari 2019 \\
\hline
\end{tabular}

\begin{abstract}
This study shows the interaction between the natural environment and human. Starting from the revelation of the rubber price implicate on the global changes in the relationship between the physical environment with the complex social (population, technological constraints, organization, culture, and social system) at the local level. It is important to see a variation of mutual dependence and modification of social-economic changes, especially traditional oil mining (illegal). Economic interests and environmental degradation threaten the fulfillment of the next generation needs. Data collection for this study through qualitative research method with in-depth interviews as primary data and is located in the three villages (Keban 1, Macang Sakti, and Lubuk Bintialo) Musi Banyuasin District). Social inequality triggered the exploitation of natural resources widely. Local community relations with nature is very instrumental to achieve welfare. For that, need to social engineering project system that future-oriented with the collaboration of local communities, corporation, and government. But the political will to achieve sustainable development should be started by the government (state).
\end{abstract}

Keywords: anthropocentrism, sustainable development, social system.

Abstrak: Studi ini melihat interaksi antara alam (lingkungan) dan manusia. Berawal dari turunnya harga getah karet global berimplikasi pada perubahan hubungan antara lingkungan fisik dengan kompleks sosial (populasi, tekhnologi, organisasi, budaya, dan sistem sosial) di tingkat lokal. Penting melihat variasi saling ketergantungan dan modifikasi terhadap perubahan sosial-ekonomi, khususnya tambang minyak tradisional (illegal). Kepentingan ekonomi dan degradasi lingkungan mengancam pemenuhan kebutuhan generasi mendatang. Pengumpulan data studi ini melalui metode penelitian kualitatif dengan wawancara mendalam sebagai data primer dan berlokasi di tiga desa (Keban 1, Macang Sakti, dan Lubuk Bintialo), Kabupaten Musi Banyuasin. Temuan menunjukkan ketidaksetaraan sosial memicu eksploitasi sumber daya alam secara luas. Hubungan masyarakat lokal dengan alam bersifat sangat instrumentalis untuk mencapai kesejahteraannya. Untuk itu, perlu proyek rekayasa sosial sistem yang berorientasi masa depan dengan kolaborasi masyarakat lokal, korporasi, dan pemerintah. Namun, kemauan politik untuk mewujudkan pembangunan berkelanjutan seharusnya dimulai dari pemerintah (Negara).

Kata kunci: antroposentrisme, pembangunan berkelanjutan, sistem sosial.

\section{Introduction}

The area of Musi Banyuasin, South Sumatera Province is one of the famous areas of oil and gas producer in Indonesia. Even known this region experience dependence until 86 percent for the acceptance of funds for the result [1]. But its traditional oil mining management (illegal) is now increasingly evident.

Exploitative behavior damage nature increasingly apprehensive in some villages the location of the mine. Rising traditional oil mining thus further alienated people from the moral values, responsibility respect, also ethics [2]. The quality of the environment degraded areas and threaten sustainable social relations [3]. Nature is not regarded as having intrinsic value, but the only instrumental economical value to meet the needs of the people [2.4-6].
Even though the hosts actually have the ability to influence society. One, environment provide the basis for the sustainability of a development [7-10]. Sustainable development is the result of the covenant in Rio de Janeiro, Brazil 1992. The agreement binds the design of environmental management at every system as well as the inherent in every state policy. The concept of sustainable development was introduced by Brundtland [11] which emphasizes justice between generations (intergenerational equity) in to meet their needs without reducing the opportunity to future generations. Basically, development sustainability includes multidimensional, both human and surroundings [12], Also miners in relation to the concept of heritage and the environment [13]. Even the ethics of the environment and sustainability [14] has become part of the education process [9], [15]. 
Associated with it, this article will explain the problem root of the environmental crisis, changes occur and the actors involved as part of an inseparable part in explaining the importance of oil mining in sustainable development. At the same time, this article will explain the efforts to follow up by using the perspective of sociology. This is useful in the study of nature that is able to give the influence on the society (confound essentially) because neither can be socially constructed.

\section{Experimental Section}

This article is based on the results of qualitative research [16], [17] located in three villages District Musi Banyuasin, i.e. the Keban 1, Macang Sakti, and Lubuk Bintialo villages. These three villages were there are hundreds of traditional oil mining location (illegal). Even though the status of the village, but the atmosphere around the location of the mining industry closely with the people and the potential damage to the environment and sustainable development. Data collected through the in-depth interviews against oil miners, capital owners, villager leaders, and the local community. In addition, observation and document study to complete data. The validity been using triangulation data, methods, and peer de-briefing.

\section{Results and Discussion}

\subsection{Location Description}

Musi Banyuasin regency area known as the oil producers of the earth. The funds for the most results from the field. A number of companies of oil and gas in the area is one of the PT ConocoPhillips, Tbk. The first known source of oil from the oil wells old Dutch heritage, Stanvac. Some villages to the location of the oil mining people (traditional).

Village producing oil mining is located in Keban 1 and Macang Sakti village included in Sanga Desa sub-district and Lubuk Bintialo included in Batanghari Leko sub-district. Basically, this third village has a social characteristic and similar demographics. The community holds fast the concept of patriarchy male greater role in taking the decision, both at the level of the family or the community. The education level of the population of average to high school level, though in the villages of Lubuk Bintialo there have been a number of college graduates. However, expenses for education turns out to be low in the village of the Keban 1 compared to the two other villages remember the location of this village quite far compared to the center of the Capital District.

Traditional oil mining is increasingly evident developed, especially after the revelation of the price of rubber and palm oil. Initially, local communities as horseshoe farmers, both rice or rubber farmers. But the beginning of the year 2013 happened degradation of rubber from $\operatorname{Rp} 16,000$ to $\operatorname{Rp} 4,000$ (1,18 USD to 0,3
USD) per kilogram. This causes many rubber landowners that allow the land without being intercepted because not how appropriate production cost rubber. While on the other side, rubber workers lost their livelihoods. This economic difficulty has spillover effects on the decrease in the level of security in some villages. The limitations of the level of education, skills, and jobs force them to search for other work. Based on the existence of oil wells old Dutch heritage and the existence of a number of the oil companies in the vicinity of the village caused the initiative a number of investors to open the oil mining itself.

Oil mining requires a number of working group [18], such as investors, security, would pull the well's oil, the buyer of crude oil, crude oil cooker, and consumers. So it is not surprising if 80 percent of the local population as oil miners. Informal relationship and family with income reached Rp 5.000 .000 per month. Lubuk Bintialo more prosperous than the two other villages are also visible from the multitude of the location of the cooking of crude oil and a large citizen spending (an average of more than $\mathrm{Rp} 2.000 .000$ per month). But the majority of the community is not to be participants and health and employment insurance.

\subsection{The roots of the crisis and traditional oil mining disaster}

The existence of traditional oil mining business causes social dilemmas, economic, culture, and environment. On the one hand, miners can become a social-economic safety for local communities. While on the other side, miners also caused a number of environmental problems, good environmental destruction, environment pollution, until the extinction of natural resources and the environment [19].

Traditional oil mining has been damage to the environment around him, especially the forests and plantations. The damage or forest degradation occurs because of the transition function of the forests to oil palm plantations and traditional oil mining business. A number of rubber land that is no longer profitable citizens any rent for investors to the opening of the land mines. Become more severe damage due to sensitive land and forest fires as a result of the production of the mine is not safe and environmental friendly. Its hydrological function keeps water resource disrupted. As a result, soil layer increasingly eroded and cause cartilage erosion and landslides. Any ecosystem disturbances occur, either as ecological, social, and cultural.

Environment pollution that happens as a result of the operation of the traditional oil is a pollution of the ground water and air. The most direct assault mining activities pollute the land and water in the form of toxic and hazardous waste contaminated mining products. The huge pit former miners left open, 
including scattered waste. Yet, there is a concern and the use of technological constraints to prepare waste with good. Even, workers using detergent (clothing soap) to extinguish the fire when compared to production using a modern fire extinguisher because of the consideration of cost. This makes the ground water wells and rivers polluted. The quality of land declined due to reduced hara element and the extinction of microorganisms. The first question of clean water in the dry season very felt the villagers Macang Sakti that does not have the river. Air pollution from gas mining results open, exhaust motor vehicle as a tool to attract oil, until the cooking process crude oil mining products. Various diseases threaten the workers and the local population, such as respiratory tract infections, asthma, nerve disorders, until impotence. More information, the impact that contained herein is an improvement in global warming and climate change.

While the extinction of natural resources and environment that came with this traditional oil mining activity in the form of extinction biodiversity, springs, and natural resources. Diminished, even extinction, biodiversity threatened the diminution of the population of birds, mammals, and other endemic animals. The habitat of flora and fauna disturbed. Opening massif miners increasingly reduce the sources of water that threatens to further contamination, drought, until the flood. Water crisis can interfere with agricultural activities and breeding farm, up to threaten a food crisis. Even the villagers have been using water packaging for the needs of their daily consumption. Oil miners activities are known to interfere with the balance of the natural resources, both renewable energy (forests and water, land) or not renewable energy (oil). The need to be serious attention together. In this case, the extinction of biodiversity caused by human behavior, especially the opening of traditional oil mining, which is only concerned with the aspect of the economy, without considering the polluted and the destruction of the environment and the ecosystem.

Traditional oil-mining environmental crises also cause the social complex problems. The villagers vulnerable an imbalance and social injustice, economics, and law. Capital owners have capital and access and political support to rule, exploit, and enjoy natural resources. Meanwhile, workers (labor) instead. Even the workers directly receive the impact of damage and environmental pollution caused by the production of the mine. More information, injustice also occurs between the sexes. Women become victims of home from this traditional mining exploration because they lost their jobs after a farm worker. Even, women are the most vulnerable groups against the pollution of the environment such as water shortages for the activity of his household, including contamination of harmful substances and other diseases. Next, injustice between generations. Current generation erodes and damage the environment, while the next generation will lose various natural resources and facing various environmental crises. Mining exploration is also vulnerable to social conflicts, both horizontal and vertical. So also with the threat of human rights violations in the form of child labor, a long working hours, job insecurity, disturbance economic life, social-cultural, health, also resettle uniqueness and local wisdom. The main things to be attentive is mine without permission is a form of injustice, real government (state) to the people.

\subsection{Changes in the natural environment of social- economic}

A traditional oil-mining exploration not only caused the changes and damage to the physical environment, but also economic changes, social, and cultural village society. Economic changes appear from transferring the livelihoods of from agriculture becomes oil miners. When as a rubber farmer they develop the system the wages for the results with massive two thirds or half of the proceeds from the sale of based on the agreement and the type of seeds. While, as miners (pemolot) they receive a reward in accordance with the amount of oil that is successful in the drop down to the surface. This means that the more oil obtained, then follow any income. Even though the distribution of the benefits from the mine is divided and managed by each working group, namely capital owners, security guards, would well, pemolot, cooking oil, and sellers of oil. Thus the group of miners more correctly seen as a corporation than as a communal land.

Social relations in a working relationship also appear to experience the changes. Even though the livelihoods in the village on the basis of the relationship between patron-client, but on the oil mining social relations tend to be exploitative. Exploitation relations appear from the distribution of which is not evenly. For those who have tight social capital owners, tend to get more convenience and benefits. It is implicated in the increase in income and welfare. Then, limited society that can access the oil mining. Thus, material and nonmaterial inequality occur.

Meanwhile, cultural change seen from the start blinded the system of values and norms of village communities. Along with the increase of the economy in the village, technological developments and any information with. But a lack of education level known to threaten the culture of rural communities and the more loss of local wisdom along with the increase of lifestyle hedonism, like: alcoholic beverages, entertainment stage, drug abuse, until free sex.

Changes in traditional oil mining village society cover a complex system (see Figure 1). 


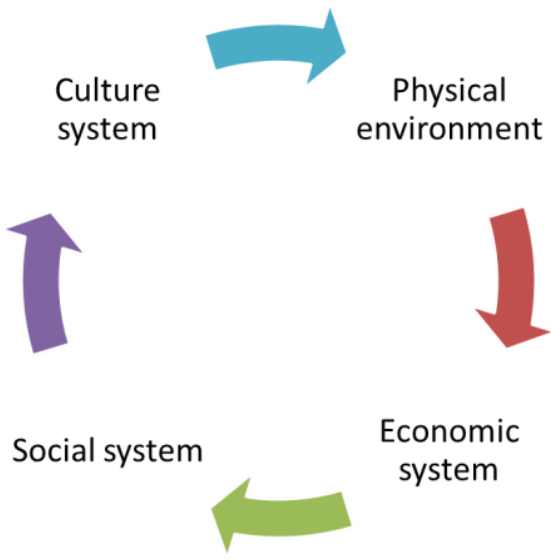

Figure 1. Changes the system in traditional oil mining community

\subsection{Mutual dependence between actor}

There is a mutual dependence relation in the complexity of ecology according to Dunlap and Catton [20] The between population, organization, environment, and technological constraints. These findings complement the concept, especially regarding social inequality and exploitation of natural resources. Economic and social segregation happens culturally and structurally.

The welfare of the imbalance in both the vertical and horizontal level. On the horizontal relations, imbalance occurs between mine workers and between the local population with migrants. Generally, local switches livelihoods become oil miners. While the inhabitants of the sojourner (Central Java) still become rice farmers. Along with the increasing luster of oil mining and the result is promising more foreigners who work in the oil mining. It more causes social envy in the distribution of the economic benefits of mining activities. Sentiment on the sense of localism villagers is related to the priority of the local rights.

While the vertical imbalance occurs between the miners with capital owners, between capital owners with your villages and your village by the local government (sub-districts, district, and the local parliament). The gap between capital owners and miners have a usual thing happened. Now, the authority of the management of the mining activities to political interests between capital owners with your villages and the local government. The aim of economic accumulation as a result of the exploitation of natural resources. This can be a direct cause of the existence of a society resistance to mining social conflict.

On the one hand, for oil corporation, the existence of traditional oil mining is considered that it does not interfere with the productivity of the company, for they do not switch to dig near the operational areas. Moreover, the existence of the oil mining was also able to reduce the level of the destruction of company oil pipeline.

The environmental impacts of mining activities related to the exploitation. Due to the mining activities damage the local ecosystem, so disrupt economic activities and the health of the community. Air pollution, land, water, biological, and has become part of this mining exploration. Even, mineral exploitation is significant as one of the causes of conflict [21].

\subsection{False paradigm}

The exploitation of nature in the form of traditional oil mining caused by the social structure and culture in society. Became dislodged cause false of perspective and behavior. Human considers himself as the center of all things (anthropocentrism) [22]. This paradigm false persists in the form of the attitudes and behavior of society toward nature and his life. Including, nature (oil) is intended to meet the needs of the people through the instrumental value land. It is on the basis of the awareness of the citizens as homo economicus.

The exploitation of increasingly evident also related development policy. Even though the management of oil and gas (Act No. 22 2001) was still under the authority of the state-owned Pertamina, not decentralized. However, the region has the authority to draw retribution from the management of oil and gas in the region. But lack of law enforcement raises the mine people that do not have this permission is thus becaming the source of the economic struggle between local elites.

The level of technological development and modernization is believed to support the widespread exploitation of natural resources. The use of a new motor as the main engine oil able to increase the accumulation.

On the other hand, increased weakness shared commitment, values, and norms to maintain and take care of nature also supports environmental degradation. Local leadership that powerless and contra people, as well as the development of individualism increasingly distanced the villagers from the noble values.

\subsection{Efforts to follow up}

The local natural wealth it has not yet been able to give prosperity to local communities, particularly oil miners. The need to change the governance of the traditional oil mining holding on the basis of mutual benefit between local communities, the next generation, miners, investors country, and nature. One of the solution to radical change how society views from anthropocentrism become biocentrism and ecocentrism. The view of human nature changed because nature is as important as the life of humans. 
Nature must also view has intrinsic value, not instrumental.

In addition to the changes, perspective needs to be followed up with changes in behavior. Nature must be protected. This stand on the development of values of morality [2] human in addressing the crisis and environmental disaster. Need to do the governance of the environment is good also a clean industry and environmental friendly.

The strengthening of decentralization urgent needed. Decentralization gives authority to the local government to manage the natural resources. But this authority can have positive or negative. During this, decentralization closely related to environmental degradation. But, decentralization will be more profitable if involving the community participation in realizing sustainable development. Then the government must have the knowledge of conservation awareness and the desire to strengthen the manage natural resources sustainable.

It is time it is important to apply sustainable development policy. In constructing not merely economic oriented, but at the same time also simultaneously consider the participation of social development and the environment. The orientation of the development will need to involve the next generation as a party that needs to have the opportunity to enjoy the results of economic development and the environment.

Other social gains in the form of real action in the form of control of civil society. Need the efforts of social movements in support of conservation and sustainable development of demanding consistency leaning toward the government, especially the State Minister of the Environment, members of the Parliament and local government and the community.

\subsection{Theoretical and practical implications}

This study considers the relationship between the physical environment and social system of the culture in the dimensions of the dynamics and sustainable development project social engineering the future system needs to consider the role of local communities, corporation, and the government.

This analysis emphasizes the local government of the district and sub-district because more directly related to the social problems of the environment that happens. The role of the domination of the state is no longer relevant because some of the representatives of the people were involved in business this exploitation. Changes in local political condition known also closely with the condition that allows for social inequity. Even though the role of local government to determine the strong-weak integration and social processes.

Social change happens at the level of the community and the government. In the community changes the orientation of economic, environmental, and social. The orientation of the economy, in fact, defaulted the values of morality in nature and each other with the emergence of a sense of localism. It threatens social integration village society. Then the state must have the political will to take an important role as a "judges". The main thing that was done to clarify the rules of the practice of oil mining community. In addition to the government need to implement effective policies and rules that have been agreed.

\section{Conclusion}

The restructuring of the global economy to support the transformation of the economy, social, culture, and local environment. The transition most people become oil miners also supports damage and pollution of the environment, until the extinction of the natural resources. In addition, threatening changes in the social system and the local culture. Imbalance of the welfare of both at the level of the horizontal and vertical. This happened because of false the radical paradigm anthropocentrism and the behavior of the exploitation of nature. Then, need to change the way of view, behavior, strengthening local community social system, until the strengthening of decentralization with the existence of political will the government.

\section{Acknowledgement}

Author mention thank you to Mr. Dr. Ridhah Taqwa and Mr. Dr. Mulyanto who have introduced writer with the study of this region with previous research. In addition, thank you for the informants, as well as to the reviewer who gives input contributing to this article.

\section{References}

[1] Bahruddin, "Hidup Pasca Berkelimpahan," Kompas, Jakarta-Indonesia, p. 6, 2016.

[2] E. Agazzi, "The issue of anthropocentrism in ethics," Ital. Oral Surg., vol. 2, no. 2, pp. 81-95, 2016.

[3] G. I. Broman and K. Robèrt, "A Framework for Strategic Sustainable Development," J. Clean. Prod., vol. in press, p. 36, 2015.

[4] K. Wil, "Organising in the Anthropocene: an ontological outline for ecocentric theorising," vol. 113, 2016.

[5] F. Morelli, P. Tryjanowski, and Y. Benedetti, "Differences between niches of anthropocentric and biocentric conservationists: Wearing old clothes to look modern?," J. Nat. Conserv.

[6] O. Holanda, S. Isotani, I. I. Bittencourt, D. Dermeval, and W. Alcantara, "An object triple mapping system supporting detached objects: A 
performance and memory usage empirical comparison," Eng. Appl. Artif. Intell., vol. 62, no. April, pp. 234-251, 2017.

[7] N. Dempsey, G. Bramley, S. Power, and C. Brown, "The Social Dimension of Sustainable Development: Defi ning Urban Social Sustainability," Sustain. Dev., vol. 19, pp. 289300, 2011.

[8] I. Singh, "Human development, nature and nurture: Working beyond the divide," Biosocieties, vol. 7, no. 3, pp. 308-321, 2012.

[9] A. G. Anghel, L. M. Drăghicescu, G. C. Cristea, G. Gorghiu, L. M. Gorghiu, and A.-M. Petrescu, "The Social Knowledge - A Goal of the Social Sustainable Development," Procedia - Soc. Behav. Sci., vol. 149, pp. 43-49, 2014.

[10] H. Mikul, N. Duic, and R. Dewil, "Environmental management as a pillar for sustainable development," Environ. Manag., vol. 203, pp. 867-871, 2017.

[11] S. Baker, Sustainable Development. New York: Routledge, 2006.

[12] C. S. Sneddon, " Sustainability' in ecological economics , ecology and livelihoods: a review," vol. 4, pp. 521-549, 2000.

[13] E. Van Doorn, "Environmental aspects of the Mining code: Preserving humankind â€TM s common heritage while opening Pardo â€TM s box ?," Mar. Policy, no. Marine Policy, pp. 1-6, 2016.

[14] A. S. Barau, L. C. Stringer, and A. U. Adamu, "Environmental ethics and future oriented transformation to sustainability in Sub-Saharan Africa," J. Clean. Prod., pp. 1-9, 2016.

[15] I. Ocetkiewicz, B. Tomaszewska, and A. Mróz, "Renewable energy in education for sustainable development. The Polish experience," Renew. Sustain. Energy Rev., vol. 80, no. May, pp. 9297, 2017.

[16] J. W. Creswell, Research Design Qualitative, Quantitative, and Mixed Methods Approaches, 2nd ed. New Delhi: Sage Publications, 2003.

[17] K. Gallagher, The Methodological Dilemma: Creative, Critical and Collaborative to Qualitative Research. New York: Routledge, 2008.

[18] V. V. Sununianti, "Labor and Sustainable Development in Traditional Oil Mining," in 1st International Geography Seminar 2017, 2017.

[19] A. S. Keraf, Krisis dan Bencana Lingkungan Hidup Global, 5th ed. Yogyakarta: Kanisius, 2010.
[20] S. Novriaty, "Pemetaan Pemikiran dalam Sosiologi Lingkungan," Masyarakat, vol. XIII, No., no. Pembangunan Sosial dan Lingkungan, pp. 7-24, 2006.

[21] D. Prayogo, "Dinamika, Sebab dan Peran Negara dalam Konflik antara Korporasi dengan Komunitas Lokal, Studi Kasus pada Industri Geotermal di Kec. Pangalengan, Kab. Bandung, Jabar," Masyarakat, vol. XIII No. 2, no. Pembangunan Sosial dan Lingkungan Hidup, pp. 34-69, 2006.

[22] A. S. Keraf, Filsafat Lingkungan Hidup, 4th ed. Yogyakarta: Kanisius, 2014. 